\title{
But Does Voting Really Feed You? Ideas About Democracy's Role in Famine and Chronic Hunger
}

\author{
Janine Hancock
}

Scarcity of democracy is often cited as the source of hunger. In this paper the origin of this idea, the arguments behind it, and its validity are examined. In doing so, different types of hunger are addressed. The author also looks at the role of government systems in the famines of Ireland, India, and Sudan and the effect that democracy has on food policy decisions in the United States. By the conclusion of this paper, the reader will be familiar with the phenomenon of citing democracy in discussions of food. A lack of democracy is not the source of hunger, and democracy is not inherently equipped to confront hunger.

A n idea common among hunger theorists Nestle (2008), and Mousseau (2005) is the inherent relationship between food security, famine, and democracy. Lack of democracy is referenced in a significant number of writings on hunger and famine as a contributing factor to, or even the sole source of, scarcity. The connection between democracy and famine is attributed to economist Amartya Sen $(1999,7)$ who famously states "no substantial famine has ever occurred in any independent and democratic country with a relatively free press," yet this popular reference never seems to warrant an explanation. In this paper I will critically examine the impact of democracy's contribution to the eradication of hunger. By blaming countries experiencing hunger for not having democracy, we dismiss the possibility of other issues that contribute to hunger and prevent its eradication.

\section{WHAT IS Hunger?}

In this paper I will discuss two types of hunger: chronic hunger and famine. According to Paarlberg (2010, 46), a famine occurs when many people die in a short period of time as a result of not having enough food. Chronic hunger, on the other hand, does not result in many quick deaths at once, but is more gradual. Those who suffer from chronic hunger may eat enough to survive but don't always get the nutrients needed to properly sustain the body (Paarlberg 2010, 32). Chronic hunger can result in stunted growth, a immunodeficiency, or other developmental issues and can have intergenerational effects. Reasons for famine are specific to each circumstance and there is never a single reason for them. It is now widely accepted that hunger is not caused by a scarcity of food, because the world produces more than enough food to feed our whole population, and much of that food goes to waste.

\section{The Pervasiveness of Democracy Comments}

References to democracy are widespread among writings on hunger and famine. In Diet for a Hot Planet, Anna Lappé (2010a, 40) mentions that: "hunger persists not because of a scarcity of food, but because of a scarcity of democracy. For democracy means, at its very core, that we each have a voice, and none among us would choose to see our families and communities go hungry." Lappé is able to explain the basic logic behind the democracy argument: people do not choose to go hungry, and with democracy they are able to overturn the unjust circumstance that finds them hungry by appealing to government.

Lappé is not alone in this observation. Mousseau (2005, iv) also attributes the scarcity of democracy as the source of hunger, without explanation, in his examination of food aid. Additionally, the Food and Agriculture Organization $(1998,24)$ commits to promoting democracy as the first step to making food a human right. Surprisingly, Paarlberg (2010) seems to be more cautious in pinpointing democracy in his comprehensive look at Food Politics by saying that it is 
"usually better than the alternative." It is interesting to note that scholars with extremely diverse political ideals such as Paarlberg, who tends to have a neoconservative, pro-technology focus, and Lappé, who has an environmental, smallfarm, anti-industry mentality, share acceptance of the idea that democracy has a positive effect on hunger.

Even authors who are not writing about chronic hunger or famine find ways to discuss democracy. Nestle $(2008,5)$ argues that the biggest pet food recall in North America is an example of democracy fulfilling its purpose because food safety was given more attention at the protest of citizens. Though Nestle is not discussing famine, the general nature of her argument is the same as those who see a connection between hunger and democracy: citizen protest invokes a government response. Johnston \& Baumann (2010) have even included democracy in the title of their book, Democracy and Distinction in the Gourmet Foodscape. However, they use the term democracy to explain the ability to make decisions regarding which food to eat and not in reference to a political governance system. Regardless, democracy appears to be a phenomenon in discussions of food and hunger.

\section{Origins of Hunger's Link to Democracy}

Whilst pinpointing democracy, Lappé explains that her mother long ago wrote about the relationship between democracy and food in her famous work, Diet for a Small Planet, which was first published in 1971. However, this work focuses on the inefficiency of production in the American food industry, suggesting vegetarianism as an alternative, and questions the effectiveness of democracy in the United States. In the introduction added for the 1991 printing of Diet for a Small Planet, Francis Moore Lappé (1991, xviii) comments, "Wherever there is hunger, democracy has not been fulfilled." It is interesting that Lappé upholds democracy as the key to preventing hunger while at the same time arguing that the US system needs to improve in order to become a true democracy; this is evidenced in her statement that her own society has moved away from democracy in favor of a greater concen- tration of economic power (Lappé 1991, 113). Lappé therefore contradicts herself. Since generally Americans are the world's major food consumers, and Lappé herself has commented that democracy has not been fully achieved in the US, there must be other factors that affect hunger.

In 1986, Lappé also co-authored a book entitled World Hunger: 12 Myths, which explores democracy and hunger in more detail. Here Lappé $(1986,5)$ argues that a lack of democracy at the family, village, national, and even international levels has led to citizens being powerless. Though Lappé feels she has found a solution to hunger, there is still an obstacle in her path to solving it. The premise of this book is to correct common myths which Lappé feels hinder the ability to prevent hunger. Lappé $(1986,7)$ states, “The principles around which many of us have come to organize our thinking about world hunger block our grasp of real solutions." While I agree with this statement, Lappé and I disagree on which principles it is that act as obstacles. Anna Lappé (2010) credits her mother as the originator of "the democracy solution," but Amartya Sen can also be attributed with this idea.

Sen's thinking on sources of hunger has shifted steadily over time. In 1981, Sen published Poverty and Famines, an Essay on Entitlement and Deprivation. This work looked at the relationship between the market system and famine, where Sen pointed out that Famine occurs when markets are not regulated (quoted in Jackson 1982). He based this idea on his experience during his childhood in Bangladesh, where famine occurred in 1943 as market prices were driven up due to a fear of food scarcity. People began to hoard food, resulting in price increases that caused lower income groups to be priced out of the food market (Paarlberg 2010, 49).

In 1989, Dreze and Sen explored another facet of "the hunger question" arguing that public action plays a vital role in eradicating hunger. Since 1989, Sen has become a strong advocate for democracy and has associated public action with democratic governance, which to be fair is a logical leap. In his article "Democracy as a Universal Value," Sen $(1999,7)$ confidently argues: "In the terrible history of famines in the world, 
no substantial famine has ever occurred in any independent and democratic country with a relatively free press. We cannot find exceptions to this rule, no matter where we look."

\section{Is Sen's Statement True?}

Zweifel and Navia (2000, 99) assert that Sen's statement has validity with the exception of India and China. They compare the infant mortality rates in countries of democracy versus dictatorships and find that there are fewer child deaths in democracies. Zweifel and Navia (2000) have chosen to examine infant mortality because it is the indicator of chronic hunger used by international organizations. One critique is that there are many factors which play a role in infant mortality, such as health care and disease control, and so this method may not directly measure chronic hunger. At the same time, I cannot think of another method that would be more effective, since deaths from disease or infection can be due to a compromised immune system caused by hunger. Hunger is extremely difficult to measure.

In any case, the reasoning of Zweifel and Navia $(2000,100)$ is along the same lines as Lappé and Sen: "Since under democracy public decisions must take into account the preferences of the majority, policies are more likely to represent the needs of that majority than they would under dictatorship." Yet it is not always the majority who would suffer from chronic hunger and therefore representing the needs of the majority may not automatically result in preventing chronic hunger. In fact, Paarlberg $(2010,36)$ points to the poor and those who live in remote rural areas as the most common sufferers of chronic hunger. While the poor in some countries may represent a majority, the trend towards urbanization suggests that those living in remote rural areas would certainly not be a majority.

Additionally, ethnic groups who are marginalized minorities may not have the political clout necessary to catch the attention of decision makers. An example is the Kurdish people of Turkey. Yegen $(2009,610)$ argues that the Kurds have become seen as "pseudo-citizens" who feel alienated from the "Turkish political community." A group that is politically alienated from the rest of society such as the Kurds may have a more difficult time making the case to government that their needs are a priority.

Returing to infant mortality, Zweifel and Navia (2000) explain the exceptions of China and India by examining local policy and government. These two countries are an exception because under the economic model used to facilitate this study, China's rates for infant mortality were much lower under dictatorship, from 1950 to 1990 , than they would expect if China had been a democracy during this time. Likewise, India had much higher rates of infant mortality as a democracy than its predicted rates under dictatorship. Zweifel and Navia $(2000,109)$ argue that in China, decision-making is not controlled at a local level, whereas in India local officials have control and so because of the large size of both countries, the national government does not translate locally, and is not as relevant a factor. Despite their reasoning, these exceptions show that chronic hunger does exist in countries with a democratic government.

Similarly, Plumper and Neumayer (2009) argue that famine mortality has occurred in democratic countries. This claim is directly in opposition to Sen's (1999) statement that famine has never occurred in a democratic country. They maintain that inactivity is sometimes a better strategy politically than preventing or reacting to famine (Plumper and Neumayer 2009, 53). While Sen $(1999,8)$ argues that there have been many threats of famine in India since 1947 but that they were prevented due to public action, Plumper and Neumayer $(2009,52)$ discuss the 1967 Bihar famine in India, which again contradicts Sen's analysis. The authors use Bihar as an illustration of how famine can easily become politicized. In this situation, the central government refused to recognize the famine until after elections. As well, the Bihar region did not hold significant power in decision making since it was only a small sector of the population, underscoring the importance that the majority plays in famine-related decisionmaking (Plumper and Neumayer 2009, 52).

These two scholars also use the Sudanese famine of the 80s to dispute another facet of Sen's (1999) argument: the importance of free 
press. While famine was occurring in the South of Sudan, the media were only interested in issues affecting Northern Sudan and so did nothing to try and affect public opinion or appeal for those suffering. Furthermore, the government encouraged militia forces to raid cattle in the South as a policy to hinder Southern rebels (Plumper and Neumayer 2009, 52-3). Plumper \& Neumayer seem to agree with Sen that the media can be an effective tool for encouraging public action, but they dispute the idea that the presence of a free press will always incite action against famine. This example also shows that democratically elected governments can have other priorities, such as trying to maintain the system of government, which can get in the way of famine prevention.

However, Plumper and Neumayer (2009, 50) admit that though famine mortality does occur in democratic states, it occurs at much lower rates than states with autocratic governments. This echoes Paarlberg's (2010, 3) comments about food policy. He remarks that democratic systems are generally better because they tend to make less food policy errors. These two claims seem to be much more reasonable than Sen's. By stating that no famine has ever occurred in a democratic country, which as we have seen in the above examples is simply not be the case, he has allowed his entire argument to be negated. I disagree that scarcity of democracy should be considered the source of hunger, whether famine or chronic, and I do not accept that democracy is at all times better equipped to prevent or address hunger than other systems. Despite that, I can accede that overall, less hunger occurs in democratic states than otherwise.

\section{Correlation or Causation? Democracy and Hunger Prevention}

Scholars seem to truly feel that democracy in its very structure and nature is inherently equipped to combat hunger. In a recent interview, Anna Lappé (2010b) commented, "If democracy is defined as everyone having a voice - and few among us would choose to go hungry or make others go hungry - then the presence of hunger reveals a deep democracy deficit." Yet if famine can occur at all in independent democracies with a free press, then the presence of famine indicates that democracy does not inherently solve hunger.

Democracy is not the only variable common to all democratic countries. Western democratic countries certainly share more than just a political system. Western countries also tend to have similar economic values, economic systems, biomedical values, and education practices, and generally are considered to be the most developed. But is it fair to say that a lack of biomedicine or a difference in values is the source of hunger? I would argue that this would be an unreasonable assumption. Perhaps the culmination of factors that allow for a longer life span in Western countries also contributes to food security. In other words, though there is an inverse correlation between democracy and hunger, I doubt that hunger is directly caused by not having democracy.

Western democracies are not immune from hunger. Indeed, it is feasible that hunger exists in all states on a small scale, as every country has some degree of people in poverty. Food banks, soup kitchens, and other food programs have been created to address chronic hunger in the west. These programs are an example of a public action that does not involve democracy, since many food banks and soup kitchens are not run by government agencies, but rather by churches or community members.

In contrast, there are also examples of democratic decision-making that do not involve citizens. Nestle $(2008,5)$ discusses how food policy regarding pet food was shaped by US citizens enacting their democratic right. Nestle supports Paarlberg's $(2010,3)$ argument that democratic states tend to make better food policy decisions. Be that as it may, there is another angle from which the pet food recall can be considered. Upon reading Pet Food Politics (Nestle 2008), I was astounded by the influence that business and lobbyists have on government decisions. The amount of support needed to generate change, and the competing interests between what is best for the health of citizens and what is best for influential industries, make it very difficult to up- 
date food safety regulations. Though citizens vote on who represent them, lobbyists and businesses have more political clout in periods between elections. It was only after the death of thousands of pets that the outcry of citizens caused an eventual reaction by government agencies. However, business lobbying prevented regulations that would have averted this entire crisis and continue to hinder the implementation of better regulations in response. Lang (2005) argues that there are two dimensions to the current food system, food control and food democracy, and that the power in this system belongs to retailers, who are gatekeepers. This example reminds us that in a democracy, there are not merely the state and citizens, but other influential players as well. Lang $(2005,736)$ maintains that "the state, food supply chain and civil society" are all competing actors in food policy-making. This idea complicates the argument that democracies always respond to their citizens. Perhaps in Ancient Greece, democracy simply involved citizens and their decisionmaking power, but it is not nearly this simple in today's democratic systems.

Though democratic states generally seem to be better off in times of famine, we know that this is not always the case, as seen in the previous discussions. Another example is the famous Irish potato famine from 1845-1850. The initial crisis is attributed to a fungus that wiped out potato crops and left farmers without income. Despite that, the British government also failed to respond to the public's requests. Harzallah (2006, $305)$ insists that the government did not react because it valued the ideology of laissez-faire. Discussions over how to respond to the famine resulted in a change in prime minister in 1846, yet this did nothing to elicit aid (Harzallah 2006, 306). In addition, the potato fungus was seen to be "an act of Divine Providence, [causing beliefs that] the government should interfere as little as possible" (Harzallah 2006, 306). The Irish famine of $1845-50$ is yet another example of a democratic system that does not appropriately respond to famine. However, because Ireland was at this time controlled by the British government, albeit democratic, it can be argued that the Irish famine does not fit into Sen's (1999) criteria as an inde- pendent democratic country with a free press: Ireland was not independent.

Nevertheless, the Irish famine is also an example of a way in which people deal with hunger without public action or adducing democratic rights: mass migration. Barraclough (1991, 137) reminds us that people have migrated in times of drought, oppression, or lack of resources for thousands of years and argues that people still use migration as a defense mechanism against hungey. Additionally, Barraclough $(1991,138)$ argues that migrants seldom find themselves in a worse circumstance after migrating. While those who migrate do nothing to change the political circumstances that contribute to hunger, the "remittances, new contacts, better information, new methods and ideas" that communities are exposed to from newcomers are equally as beneficial (Barraclough 1991, 139). This is an important point in the discussion of democracy and public participation: there are other responses to hunger than only public outcry. Migration puts control into the hands of the people instead of waiting for government to act. It does not involve attracting attention to oneself, and because of this, I can see why it may be a more attractive alternative for those who are not extroverted.

Is Governance Problematic IN the Hunger Debate?

Perhaps including governance isn't problematic. It would be hypocritical of me to suggest that we shouldn't include this idea, since I am advocating that we need to stop ignoring other factors in this debate.

Yet there is a tendency among scholars, including those mentioned throughout this paper, to focus solely on democracy. This tendency is indeed problematic because it limits the exploration of other contributing factors and thereby reduces the complicated problem of hunger into a simplistic situation. Discussions of food and democracy tend to understate the importance of the hunger issue by instead emphasizing how great democracy is.

By focusing on democracy as the solution, we put blame on countries that have not been "wise" or "proactive" enough to also adopt de- 
mocracy. Blaming those who are suffering from hunger does not do anything to address the problem, especially since transition to democracy can be a painful process.

But most importantly, determining that the solution is democracy can demonstrate an inherent underlying ethnocentrism. By deciding that our system is the best system and everyone else should adopt it, we fail to respect the idea that different systems may be more effective for different people with different cultural values. Our capitalist, democratic system emphasizes individual welfare, while other systems may put more emphasis on communal well-being, or may fall somewhere in the middle of these two. We need to practice cultural relativism in this regard.

In this paper I have critiqued the concepts that scarcity of democracy is the source of hunger and that democracy is inherently equipped to respond to hunger. These concepts are ingrained in the minds of hunger theorists, but automatic acceptance of these ideas needs to be reevaluated. I truly agree with Francis Moore Lappé (1987, 5) that "the way people think about hunger is the greatest obstacle to ending it."

\section{ACKNOWLEDGEMENTS}

I'd like to thank Dr. Helen Vallianatos and my classmates from ANTHR 416 Nutritional Anthropology who have opened my mind to the anthropology of food politics. This paper was written as an assignment for this class.

\section{References Cited}

Barraclough, Solon L. 1991. An End to Hunger: The Social Origins of Food Strategies. London: Zed Books, Ltd.

Dreze, Jean, and Amartya Sen. 1989. Hunger and Public Action. Oxford: Claredon Press.

Food and Agriculture Organization. 1998.

The Right to Food in Theory and Practice. Rome: FAO.

JaCKSOn, Tony. 1982. "Review of Poverty and Famines." The Economic Journal 92 (366): 449451.

Johnston, Josee, and Shyon Baumann. 2010.

Foodies. Ithaca, NY: Cornell University Press.

Harzallah, Mohamad S. 2006. "Food Supply and Economic Ideology: Indian Corn Relief During the Second Year of the Great Irish Famine (1847)." The Historian 68 (2): 305-23.

Lang, Tim. "Food Control or Food Democracy? Re-engaging Nutrition with Society and the Environment." Public Health Nutrition 8: 730737.

Lappé, Anna. 2010a. Diet for a Hot Planet. New York: Bloomsbury.

. 2010b. Interveiw, "August 26. Five Questions For... Anna Lappé." Global Food Security: Examining the Challenges to Global Food Security. Electronic document, http://foodcrisis.foreignpolicyblogs.com/2010/08/26/ five-questions-foranna-Lappé/, accessed November 30, 2010.

Lappé, Francis Moore. 1991. Diet for a Small Planet. USA: Balantine Books.

. 1986. World Hunger: 12 Myths. New York, NY: Grove Press.

Mousseau, Frederic. 2005. Food Aid or Food Sovereignty? Oakland: The Oakland Institute.

Nestle, Marion. 2008. Pet Food Politics. Berkeley: University of California Press.

PaArlberg, Robert. 2010. Food Politics. Oxford: Oxford University Press.

Plumper, Thomas, and Eric Neumayer. 2009. "Famine Mortality, Rational Political Inactivity, and International Food Aid." World Development 37: 50-61.

Sen, Amartya. 1999. "Democracy as a Universal Value." Journal of Democracy 10 (3): 3-17.

Yegen, Mesut. 2009. "'Prospective Turks' or 'Pseudo-Citizens': Kurds in Turkey." Middle East Journal 63 (4): 597-615.

Zweifel, Thomas, and Patricio Navia. 2000. "Democracy, Dictatorship and Infant Mortality." Journal of Democracy 11 (2): 99-114. 